\title{
Nineteenth Century Black and White US Statures: The Primary Sources of Vitamin D and their Relationship with Height
}

\author{
SCOTT ALAN CARSON \\ CESIFO WORKING PAPER No. 2497 \\ CATEGORY 3: SOCIAL PROTECTION \\ DECEMBER 2008
An electronic version of the paper may be downloaded
- from the SSRN website:
- from the RePEc website: www.SSRN.com
Www.RePEc.org \\ - from the CESifo website: \\ www.CESifo-group.org/wp
}




\title{
Nineteenth Century Black and White US Statures: The Primary Sources of Vitamin D and their Relationship with Height
}

\begin{abstract}
Vitamin D is vital in all vertebrates because it allows them to absorb more calcium from their diets, contributing to stronger skeletal systems and stature growth. Using a new source of 19th century US state prison records, this study contrasts the statures of comparable AfricanAmericans and whites by the primary sources of vitamin D production: time exposed to solar radiation, skin pigmentation, and nativity. Greater insolation (vitamin D production) is documented here to be associated with taller black and white statures, and a considerable share of the stature differential by socioeconomic status was related to insolation.
\end{abstract}

JEL Code: I10, J01, J15, J16, N81.

Keywords: socioeconomic status, vitamin D, insolation, 19th century US statures.

\author{
Scott Alan Carson \\ University of Texas, Permian Basin \\ 4901 East University \\ Odessa, TX 79762 \\ USA \\ Carson_S@utpb.edu
}

Please do not cite without permission from the author.

I appreciate comments from participants at the Western Social Science Association and Social Science History Association meetings. Comments from Tom Maloney, Larry Wimmer, Peter Coclanis, Stanley Engerman, Jeremy Atack, Bob Margo, Harold Christianson, and John Komlos were particularly helpful. Craig O. Davis and Anita Voorhies provided excellent research assistance. 
Nineteenth Century Black and White US Statures: the Primary Sources of Vitamin D and their Relationship with Height

\section{Introduction}

Modern studies illustrate the beneficial role that vitamin D has on health outcomes, ${ }^{1}$ and the pathways by which vitamin D influences health have come into focus. Vitamin D helps calcium absorption, facilitates bone formation, and stature growth; vitamin D also acts as an autoimmune regulator and may limit hyper proliferate cell growth, subsequently, the spread of cancer (Holick, 2004, p. 366). Unlike other vitamins and nutrients, the primary source of vitamin D is not dietary but is produced internally in the stratum corneum by the synthesis of sunlight and cholesterol. Vitamin D production is therefore related to the physical environment, indicating occupations are related to vitamin D production. ${ }^{2}$ This paper uses a large source of $19^{\text {th }}$ century US male prisoners to illustrate how stature variation was associated with the three most important sources of vitamin D production, which, in order of importance, are the amount of time exposed to sunlight, skin pigmentation, and nativity (Holick et al., 1981, p. 590).

Vitamin D is related to statures and statures are used to measure biological and economic conditions in both contemporary and historical studies. A populations' average

\footnotetext{
${ }^{1}$ Multiple cancers — including prostate, colorectal, breast, and ovarian — are linked to insufficient vitamin D. Other chronic diseases, such as multiple sclerosis and rheumatoid arthritis, have been tied to insufficient vitamin D consumption.

${ }^{2}$ Recognizing the incidence of rickets, in the 1930s, the US government advocated the supplementation of the US milk supply with vitamin D to promote stronger bone formation.
} 
stature reflects the net cumulative balance between nutrition, disease exposure, work, and the physical environment. By considering average versus individual stature, genetic differences are mitigated, leaving only the influences of the economic and physical environments on stature. When diets or the physical environments improve, average stature increases and decreases when diets become less nutritious, disease environments deteriorate, or the physical environment places more stress on the body. Greater direct sunlight (insolation) produces more vitamin $\mathrm{D}$, and vitamin $\mathrm{D}$ is related to adult terminal stature (Xiong et al, 2005, pp. 228, 230-231; X-ZLiu et al, 2003; Ginsburg et al 1998; Uitterlinden et al, 2004). ${ }^{3}$ Hence, stature provides significant insights into understanding historical processes, especially in the $19^{\text {th }}$ century US, where other measures for living standards are limited.

It is against this backdrop that this paper considers a sample of over $180,00019^{\text {th }}$ century black and white male inmates that covers from slavery, through Reconstruction, and the end of the $19^{\text {th }}$ century. ${ }^{4}$ Two issues are considered. First, because occupations represent time spent outdoors, what was the relationship between stature and insolation by occupation? Results presented here illustrate that workers who worked outdoors, such as farmers and laborers, were taller than workers who worked indoors, such as whitecollar and skilled workers, indicating that taller statures were associated with exposure to

\footnotetext{
${ }^{3}$ Insolation is an acronym for incident solar radiation, and is a measure for sunlight energy received for a given surface area at a given time. If w equals watts, m equals meters, and i equals insolation, $i=\frac{w}{m^{2}}=\frac{k w h}{m^{2} \cdot d a y}$.

${ }^{4}$ The total number of inmates recorded in the Texas prison between 1873 and 1922 is over 50,000. This includes nearly 8,000 observations of Mexicans, females, and Europeans not considered here.
} 
direct sunlight. Second, after considering socioeconomic status, what were the primary sources of stature variation? ${ }^{5}$ The majority of $19^{\text {th }}$ century stature differentials by socioeconomic status were attributable to insolation and race, indicating that the primary source of vitamin D production were the amount of time spent outdoors, skin pigmentation, and nativity.

2. Vitamin D, Calcium, and $19^{\text {th }}$ Century Black and White Statures Any comparison between $19^{\text {th }}$ century black and white statures must account for an ironic finding. Black and white statures have the ability to reach comparable average levels when brought to maturity under similar biological conditions (Eveleth and Tanner, 1966, Appendix. Tables 5, 29, and 44; Tanner, 1977, pp. 341-342; Margo and Steckel, 1982). However, $19^{\text {th }}$ century black and white statures demonstrate that blacks were consistently shorter than whites, but we are less certain of the source for this difference (Margo and Steckel, 1982; Sünder, 2004; Carson, 2008). Moreover, any explanation must account for a robust geographical finding: Southern blacks were shorter than Southern whites, and Northern blacks were shorter than Northern whites (Margo and Steckel, 1992, p. 516). A common explanation for taller mulatto statures is that $19^{\text {th }}$ century social and economic forces favored fairer complexions over lighter complexions, and lighter colored blacks benefited from these social and economic institutions (Margo and Steckel, 1982, p. 521; Bodenhorn, 1999, p. 983). An additional explanation for this

\footnotetext{
${ }^{5}$ Margo, Robert and Richard Steckel, "Heights of American Slaves," 519. Modern studies demonstrate that well-fed Americans of African descent reach approximately the same statures as Europeans and Americans of European descent; hence, variation in genetics may play minor roles in black-white stature differentials.
} 
white stature advantage and why Southerners were taller than Northerners may be related to biology, especially its relation to geography (Carson, 2008, pp. 822-825). Calcium and vitamin D are two chemical elements required throughout life for healthy bone and teeth formation; however, their abundance are most critical during younger ages (Wardlaw, Hampl, and Divilestro, 2004, p. 394-396; Tortolani et al, 2002, p. 60). Calcium generally comes from dairy products, and vitamin D is typically not dietary but its primary source is the synthesis of cholesterol and sunlight in the epidermis' stratum granulosum (Holick, 2004, pp. 363-364; Nesby-O'dell, 2002, p. 187; Loomis, 1967, p. 501; Norman, 1998, p. 1108; Holick, 2007).

Vitamin D is vital in all vertebrates because it allows them to absorb more calcium from their diets and contributes to stronger skeletal systems (Jablonski, 2006, p. 62). ${ }^{6}$ After the circulatory system contains sufficient amounts of vitamin D and to avoid vitamin D toxicity, vitamin D production is restricted within the stratum granulosum and residual vitamin D is broken down into inert matter (Holick et al, 1981, pp. 591-592; Jablonski, 2006, p. 62; Holick, 2001, p. 20; Holick, 2004, p. 363). This self-limiting vitamin D effect may account for some of the difference between how black and white statures were associated with insolation, because at North American latitudes whites are closer than blacks to the natural threshold where vitamin D production is curtailed (Carson, forthcoming). At the opposite extreme, insufficient vitamin D has been linked to rickets, osteomalasia, auto-immune diseases, and certain cancers (Holick, 2001, p. 28; Garland et al, 2006, pp. 252-256; Grant et al, 2003, p. 372).

Vitamin D production also depends on melanin (skin pigmentation) in the stratum corneum (Norman, 1998, p. 1108), and lighter colored $19^{\text {th }}$ century blacks were

\footnotetext{
${ }^{6}$ There are few dietary sources of vitamin D.
} 
consistently taller than darker pigmented blacks (Tanner, 1977; Steckel, 1979, pp. 374376; Margo and Steckel, 1982, pp. 532-34, Table 6; Bodenhorn, 1999, 2002; Xiong et al, 2005, pp. 228, 231; Z Liu, 2003, p. 825). Higher melanin concentrations in the stratum corneum interferes with vitamin D's synthesis in the stratum granulosum, and darker pigmentation filters between 50 to 95 percent of the sunlight that reaches the stratum granulosum (Jablonski, 2006, p. 80-81; Kaidbey et al., 1979, pp. 249 and 253; Loomis, 1967, p. 502; Weisberg et al, 2004, p. 1703S; Holick, 2007, p. 270). ${ }^{7}$ Therefore, a complete explanation to address the stature differential between whites and blacks may be related to biology and vitamin $\mathrm{D}$ production.

\section{Data}

\section{Prison Data}

The data used to study black and white statures is part of a large $19^{\text {th }}$ century prison sample, and using $19^{\text {th }}$ century statures is essential when considering the relationship between D produced from insolation, because the US fortified its food supply in the 1930s to reduce the incidence of rickets. All state prison repositories were contacted and available records were acquired and entered into a master data set. These prison records include Arizona, California, Colorado, Idaho, Illinois, Kansas, Kentucky, Missouri, New Mexico, Ohio, Oregon, Pennsylvania, Texas, and Washington (Table 1). Most blacks in the sample were imprisoned in the Deep South or Border StatesKentucky, Missouri, and Texas. Most whites in the sample were imprisoned in Missouri

\footnotetext{
${ }^{7}$ To address rickets in the US population, in the 1930s the federal government advocated fortification of the US milk supply with vitamin D (Holick, 2004, p. 1679S).
} 
and Texas, but Northern whites were also from Illinois, Ohio, and Pennsylvania. The Far West is also represented in the sample.

Table 1, African-Americans and Whites in Nineteenth Century US State Penitentiaries

\begin{tabular}{l|cccc}
\hline & Blacks & \multicolumn{3}{c}{ Whites } \\
\hline Prison & $\mathrm{N}$ & Percent & $\mathrm{N}$ & Percent \\
Arizona & 148 & .25 & 1,579 & 1.27 \\
California & 433 & .74 & 8,230 & 6.61 \\
Colorado & 921 & 1.57 & 7,021 & 5.63 \\
Georgia & 1,315 & 2.24 & 157 & .13 \\
Idaho & 104 & .18 & 2,074 & 1.66 \\
Illinois & 1,221 & 2.08 & 9,942 & 7.98 \\
Kansas & 977 & 1.66 & 4,082 & 3.28 \\
Kentucky & 6,243 & 10.62 & 6,650 & 5.34 \\
Missouri & 10,479 & 17.83 & 23,787 & 19.09 \\
New Mexico & 344 & .59 & 1,998 & 1.60 \\
Ohio & 5,279 & 8.98 & 24,841 & 19.94 \\
Oregon & 61 & .10 & 2,040 & 1.64 \\
Pennsylvania & 3,899 & 6.63 & 16,026 & 12.86 \\
Texas & 27,356 & 46.54 & 16,171 & 12.98 \\
Total & 58,780 & 100.00 & 124,598 & 100.00 \\
\hline
\end{tabular}

Source: Data used to study black and white anthropometrics is a subset of a much larger $19^{\text {th }}$ century prison sample. All available records from American state repositories have been acquired and entered into a master file. These records include Arizona, California, Colorado, Idaho, Illinois, Kansas, Kentucky, Missouri, New Mexico, Ohio, Oregon, Pennsylvania, Texas, Utah, and Washington.

Notes: Stature is in centimeters. The occupation classification scheme is consistent with Ferrie (1997). 
All historical height data have various biases, and prison and military records are the most common source of historical height records. One common shortfall for military samples is a truncation bias imposed by minimum stature requirements (Fogel et al, 1978, p. 85; Sokoloff and Vilaflor, 1982, p. 457, Figure 1). Prison records do not implicitly suffer from such a constraint and the subsequent truncation bias observed in military samples. However, prison records are not above scrutiny. The prison data may have selected many of the materially poorest individuals, although there are skilled and agricultural workers in the sample. While prison records are not random, the selectivity they represent have their own advantages in stature studies, such as being drawn from lower socioeconomic groups, those most vulnerable to economic change (Bogin, 1991, p. 288; Komlos and Baten, 2004, p. 199). For height as an indicator of biological variation, this kind of selection is preferable to that which marks many military records - minimum height requirements for service (Fogel, 1978, p. 85; Sokoloff and Vilaflor, 1982, p. 457, Figure 1).

There also is concern over entry requirements, and physical descriptions were recorded by prison enumerators at the time of incarceration as a means of identification, therefore, reflect pre-incarceration conditions. Between 1830 and 1920, prison officials routinely recorded the dates inmates were received, age, complexion, nativity, stature, pre-incarceration occupation, and crime. All records with complete age, stature, occupations and nativity were collected. There was great care recording inmate statures because accurate measurement had legal implications for identification in the event that inmates escaped and were later recaptured. ${ }^{8}$ Arrests and prosecutions across states may

\footnotetext{
${ }^{8}$ Many inmate statures were recorded at quarter, eighth, and even sixteenth increments.
} 
have resulted in various selection biases that may affect the results of this analysis. However, black and white stature variations within US prisons are consistent with other stature studies (Steckel, 1979; Margo and Steckel, 1982; Komlos, 1992; Komlos and Coclanis, 1997; Bodenhorn, 1999; Sünder, 2004). Because the purpose of this study is $19^{\text {th }}$ century male black and white statures, females and immigrants are excluded from the analysis.

Inmate enumerators were quite thorough when recording inmate complexion and occupation. For example, enumerators recorded inmates' race in a complexion category, and African-Americans were recorded as black, light-black, dark-black, and various shades of mulatto (Komlos and Coclanis, 1997). Enumerators recorded white complexions as light, medium, dark, and fair. The white inmate complexion classification is further supported by European immigrant complexions, which were always of fair complexion and were also recorded as light, medium, and dark. ${ }^{9}$ While mulatto inmates possessed genetic traits from both European and African ancestry, they were treated as blacks in the $19^{\text {th }}$ century US and are grouped here with blacks when comparing whites to blacks.

Enumerators recorded a broad continuum of occupations and defined them narrowly, recording over 200 different occupations, which are classified here into four categories: merchants and high skilled workers are classified as white-collar workers; light manufacturing, craft workers, and carpenters are classified as skilled workers;

\footnotetext{
${ }^{9}$ I am currently collecting $19^{\text {th }}$ century Irish prison records. Irish prison enumerators also used light, medium, dark, fresh and sallow to describe white prisoners in prisons from a traditionally white population. To date, no inmate in an Irish prison has been recorded with a complexion consistent with African heritage.
} 
workers in the agricultural sector are classified as farmers; laborers and miners are classified as unskilled workers (Tanner, 1977, p. 346; Ladurie, 1979; Margo and Steckel, 1992; p. 520). Unfortunately, inmate enumerators did not distinguish between farm and common laborers. Since common laborers probably encountered less favorable biological conditions during childhood and adolescence, this potentially overestimates the biological benefits of being a common laborer and underestimates the advantages of being a farm laborer.

Because the youth height distribution is itself a function of the age distribution, a youth height index is constructed that standardizes for age to determine how statures were distributed and whether there were arbitrary truncation points imposed on inmate stature, either by law enforcement or state legislation. The age adjusted youth stature index is calculated by first calculating the average stature for each age group; each observation is then divided by the average stature for the relevant age group (Komlos, 1987, p. 899). Figure 1 demonstrates that black and white statures were distributed approximately normal and there is no evidence of age heaping or arbitrary truncation points. 
Table 2, Nineteenth-Century Black and White U.S. State Penitentiary Age, Birth

Decades, Occupations, and Nativity

\begin{tabular}{|c|c|c|c|c|c|c|c|c|}
\hline & White & & & & Black & & & \\
\hline Ages & $\mathrm{N}$ & Percent & Mean & S.D. & $\mathrm{N}$ & Percent & Mean & S.D. \\
\hline Teens & 16.821 & 13.50 & 169.76 & 6.70 & 11,178 & 19.02 & 167.98 & 7.46 \\
\hline $20 \mathrm{~s}$ & 63.876 & 51.27 & 171.97 & 6.52 & 31,711 & 53.95 & 171.10 & 6.88 \\
\hline $30 \mathrm{~s}$ & 27.054 & 21.71 & 172.01 & 6.47 & 10,230 & 17.40 & 10,230 & 6.72 \\
\hline $40 \mathrm{~s}$ & 10.947 & 8.79 & 171.90 & 6.51 & 3,779 & 6.43 & 170.73 & 6.80 \\
\hline $50 \mathrm{~s}$ & 4,352 & 3.49 & 171.62 & 6.51 & 1,338 & 2.28 & 170.36 & 6.98 \\
\hline $60 \mathrm{~s}$ & 1,315 & 1.07 & 171.25 & 6.73 & 452 & .77 & 169.80 & 6.49 \\
\hline $70 \mathrm{~s}$ & 233 & .19 & 170.94 & 6.42 & 92 & .16 & 169.03 & 5.91 \\
\hline \multicolumn{9}{|l|}{ Birth } \\
\hline \multicolumn{9}{|l|}{ Decade } \\
\hline $1800 \mathrm{~s}$ & 906 & .73 & 172.41 & 6.50 & 195 & .33 & 169.42 & 6.27 \\
\hline $1810 \mathrm{~s}$ & 2,467 & 1.98 & 172.52 & 6.56 & 647 & 1.10 & 169.81 & 6.96 \\
\hline $1820 \mathrm{~s}$ & 4,202 & 3.37 & 172.45 & 6.80 & 848 & 1.44 & 169.29 & 7.02 \\
\hline $1830 \mathrm{~s}$ & 7,994 & 6.42 & 171.79 & 6.66 & 1,517 & 2.58 & 170.20 & 6.86 \\
\hline $1840 \mathrm{~s}$ & 14,539 & 13.27 & 171.46 & 6.52 & 4,521 & 7.69 & 170.22 & 6.88 \\
\hline $1850 \mathrm{~s}$ & 25,075 & 20.12 & 171.31 & 6.69 & 9,866 & 16.78 & 170.71 & 7.13 \\
\hline $1860 \mathrm{~s}$ & 25,368 & 20.36 & 171.70 & 6.54 & 11,687 & 19.88 & 170.87 & 7.22 \\
\hline $1870 \mathrm{~s}$ & 22,206 & 17.82 & 171.66 & 6.52 & 13,520 & 23.00 & 170.52 & 7.05 \\
\hline $1880 \mathrm{~s}$ & 12,847 & 10.31 & 171.74 & 6.50 & 10,277 & 17.48 & 170.25 & 6.99 \\
\hline $1890 \mathrm{~s}$ & 6,594 & 5.29 & 171.96 & 6.52 & 5,259 & 8.95 & 170.32 & 6.96 \\
\hline $1900 \mathrm{~s}$ & 400 & .32 & 170.80 & 6.22 & 443 & .75 & 169.41 & 7.30 \\
\hline \multicolumn{9}{|l|}{ Occupation } \\
\hline White- & 13,780 & 11.06 & 171.33 & 6.37 & 2,346 & 3.99 & 1.69 .77 & 6.75 \\
\hline \multicolumn{9}{|l|}{ Collar } \\
\hline Skilled & 32,133 & 25.79 & 171.29 & 6.38 & 6,249 & 10.63 & 170.20 & 6.93 \\
\hline Farmer & 16,563 & 13.29 & 173.19 & 6.44 & 5,931 & 10.09 & 171.79 & 6.85 \\
\hline Unskilled & 55,927 & 44.89 & 171.56 & 6.66 & 42,998 & 73.15 & 170.42 & 7.09 \\
\hline No & 6,195 & 4.97 & 170.98 & 7.14 & 2,346 & 3.99 & 169.34 & 7.88 \\
\hline \multicolumn{9}{|l|}{ Occupation } \\
\hline \multicolumn{9}{|l|}{ Nativity } \\
\hline Northeast & 4,029 & 3.23 & 170.70 & 6.31 & 240 & .41 & 169.52 & 6.51 \\
\hline Middle & 32,334 & 25.95 & 170.09 & 6.36 & 4,092 & 6.96 & 168.47 & 6.74 \\
\hline Atlantic & & & & & & & & \\
\hline Great & 32,629 & 26.19 & 171.88 & 6.42 & 3,501 & 5.96 & 170.18 & 6.97 \\
\hline Lakes & & & & & & & & \\
\hline Plains & 17,838 & 14.32 & 171.94 & 6.38 & 7,772 & 13.22 & 169.27 & 6.84 \\
\hline Southea & 21,854 & 17.54 & 172.91 & 6.66 & 21,985 & 37.40 & 170.26 & 7.01 \\
\hline Southwest & 10,173 & 8.16 & 173.63 & 6.81 & 20,726 & 35.26 & 171.67 & 7.10 \\
\hline Far West & 5,741 & 4.61 & 170.65 & 6.59 & 464 & .79 & 169.27 & 6.78 \\
\hline
\end{tabular}

Source: See Table 1. 
Notes: Stature is in centimeters. Youth age is between ages 15 and 22. The occupation classification scheme is consistent with Ferrie (1997); The following geographic classification scheme is consistent with Carlino and Sill (2000): New England=CT, ME, MA, NH, RI and VT; Middle Atlantic= DE, DC, MD, NJ, NY, and PA; Great Lakes= IL, IN, MI, OH, and WI; Plains= IA, KS, MN, MO, NE, ND, and SD; South East= AL, AR, FL, GA, KY, LA, MS, NC, SC, TN, VA, and WV; South West=AZ, NM, OK, and TX; Far West= CA, CO, ID, MT, NV, OR, UT, WA, and WA. Stature difference is average white stature less average black stature.

Table 2 presents black and white inmates' age, birth decade, occupations, and nativity proportions. Although average statures are included, they are not reliable because of possible compositional effects, which are accounted for in the regression models that follow. Whites were a larger portion of the prison population than blacks; 68.03 percent of the US prison population was white. Blacks were less likely to be incarcerated during the early $19^{\text {th }}$ century; however, with passage of the $13^{\text {th }}$ amendment, slave owners no longer had claims on black labor, and free blacks who broke the law were turned over to state penal systems to exact their social debt. Age percentages demonstrate that black inmates were incarcerated at younger ages, while whites were incarcerated at older ages. Southern law evolved to favor plantation law, which generally allowed slave owners to recover slave labor on plantations while slaves were punished (Komlos and Coclanis, 1997, p. 436; Wahl, 1996, 1997; Friedman, 1993). Whites within $19^{\text {th }}$ century US prisons were more likely than blacks to be white-collar, skilled workers, and farmers were less likely to be unskilled. 


\section{United States’ Insolation}

To account for the relationship between vitamin $\mathrm{D}$ and stature, a state-level measure is constructed that accounts for solar radiation. Insolation is the incoming direct sunlight that reaches the earth, its atmosphere, and surface objects. Insolation is also the primary source of vitamin D (Holick, 1991, p. 590; Holick, 2007, p. 270). Because of its distance from the equator, European insolation is lower than African insolation, and before their migration to North America, Europeans had to be more efficient in vitamin D production in low insolation latitudes. Before their forced migration to North America, Africans were exposed to considerable insolation, which was significantly greater than the insolation received by their progeny in the US. Because of its size, Africa has a large insolation variation, and because of its proximity to the equator, its average insolation is greater than the insolation received in the US. For example, from a random sample of western African sites, West Africa receives approximately 5.6 hours of direct insolation per day with a standard deviation of .53 hours; however, the US only receives 4.10 hours of direct sunlight per day with a standard deviation of .61 hours and the difference is significant at acceptable levels. ${ }^{10}$

Because US historical insolation is unavailable, a modern insolation index (19932003 ) is constructed, and monthly insolation values are measured from January through June. The insolation index measures statewide average insolation levels across each of

\footnotetext{
${ }^{10}$ Western African sites include Ouagadougou, Burkina Faso; Yaoundé, Cameroon; Bangui, Central African Republic; Accra, Ghana; Gambia, Gambia; Conakry, Guinea; Liberia; Nouakchott, Mauritania; Niamey, Nigeria; Freetown, Sierra Leone; Dakar, Senegal.
} 
the states based on the hours of direct sunlight per day at county centroids in each state. ${ }^{11}$ Each state estimate was then determined by summing the average hours of direct sunlight for each county (at its centroid), weighted by the proportion of the county's total land area (in square miles) to the state's total land area (in square miles). While this index is a rough approximation for historical insolation, it provides sufficient detail to capture state latitudinal insolation variation and consequently, vitamin D production. Predictably, Southern states have greater insolation than Northern states. For example, Texas receives 1.43 , or 29 percent, more hours of direct sunlight per day than New York. It is also difficult to interpret insolation's net direct effect on human health, because greater insolation reduces calories required to maintain body temperature and produces more vitamin $\mathrm{D}$, but greater insolation also warms surface temperatures, which may have made disease environments less healthy from water-born diseases, especially in the South (Steckel, 1992, p. 501).

4. The Comparative Socioeconomic Effects of Demographics and Insolation on Black and White Stature

The timing and extent of a population's stature variation not only reflects the cumulative relationship between diet and disease, but also the distribution of wealth, population change, sectoral shifts in production, and migration (Steckel, 1994, p. 16; Lynch and Kaplan, 1997, pp. 305-308). Stature variation is also related to hours exposed

\footnotetext{
${ }^{11}$ Insolation is not the insolation in the county that surround's the state's centroid, but insolation in each county's geographic center. The range of state insolation values extends from Maine's minimum of 3.43 hours of direct sunlight to Arizona's maximum of 5.22 hours of direct sunlight per day.
} 
to direct sunlight (Carson, 2008, p. 821-824), and in $19^{\text {th }}$ century America, the bulk of the labor force worked in outdoor occupations (Rosenbloom, 2002, p. 88). To isolate the relationship between stature relative to the three main sources of vitamin $\mathrm{D}$, we test how race, demographics, nativity, migration, and insolation were associated with $19^{\text {th }}$ century statures by socioeconomic status. Because exposure to insolation is sensitive to occupations, individuals are partitioned into skilled, agriculture, and unskilled occupations. The stature of the $\mathrm{i}^{\text {th }}$ individual is assumed to be related with age, birth period, nativity, migration status, and insolation. If vitamin $\mathrm{D}$ contributed to differences in $19^{\text {th }}$ century stature, the hours of direct sunlight, skin pigmentation, and nativity will be related to individual statures.

$$
\begin{gathered}
\text { Centimeter }_{i}=\beta_{0}+\beta_{1} \text { Race }_{i}+\sum_{j=12}^{70 s} \beta_{j} \text { Age }_{i, j}+\sum_{t=1800}^{1900} \beta_{t} \text { Birth }_{i, t}+\sum_{n=1}^{6} \beta_{n} \text { Nativity }_{i, n} \\
\sum_{n=1}^{6}+\beta_{\text {Mig }} \text { Migrant }_{i, \text { Mig }}+\sum_{d=1}^{4} \beta_{d} \text { Migrant Direction }_{i, d}+\beta_{\text {Insol }_{\text {Insolation }}, \text { Insol }}+ \\
B_{\text {Insol }^{2}} \text { Insol }_{i, \text { Insol }}^{2}+\varepsilon_{i}
\end{gathered}
$$

Black and mulatto race dummy variables are included to account for how skin pigmentation was related with vitamin D and stature. Dummy variables are included for individual youth ages 14 through 22; adult age dummies are included for ten year age intervals from the 30 s through the 70 s. Birth decade dummies are in ten year intervals from 1800 through 1899 . Nativity dummy variables are included for birth in Northeast, Middle Atlantic, Great Lakes, Southeast, Southwest, and Far West regions. A dummy variable accounts for migration status and directional migration dummy variables are 
included to account for North-South migrations. ${ }^{12}$ If insolation was a driving force in stature growth, northward moves will have adverse stature effects, and southward moves will be associated with taller statures. Continuous insolation and insolation difference variables between receiving and sending location are added to account for insolation and vitamin D production.

Four models are presented. Model 1 considers workers in the three pooled occupations: skilled, farmers, and unskilled. Model 2 considers only how skilled workers' statures varied with observable characteristics. Models 3 and 4 do the same for farmers and unskilled workers

\footnotetext{
${ }^{12}$ North1 is an intermediate move from Southern to Central or Central to Northern states. North2 is a long distance move from Southern to Northern states. South1 is a move from a Northern to Central or Central to Southern state. South2 is a move from Northern to Southern states. Northern states include Maine, Vermont, New Hampshire, Massachusetts, Connecticut, Rhode Island, New York, New Jersey, Pennsylvania, Michigan, Wisconsin, Iowa, Minnesota, North Dakota, South Dakota, Wyoming, Montana, Idaho, Oregon, and Washington. Central states include Delaware, Maryland, Virginia, Wes Virginia, Kentucky, Indiana, Illinois, Missouri, Nebraska, Kansas, Colorado, Utah, Nevada, and California. Southern states include North Carolina, South Carolina, Georgia, Florida, Alabama, Mississippi, Tennessee, Arkansas, Louisiana, Oklahoma, Texas, New Mexico, and Arizona. The binary variable North1 is an intermediate move from Southern to Central or Central to Northern states. North2 is a long distance move from Southern to Northern states. South1 is a move from a Northern to Central or Central to Southern state. South2 is a move from Northern to Southern states.
} 
Table 3, National Stature Models related to Demographics, Birth Period,

Migration, and Insolation by Socioeconomic Status

\begin{tabular}{|c|c|c|c|c|c|c|c|c|}
\hline & Total & $S E$ & Skilled & $S E$ & Farmers & $S E$ & Unskilled & $S E$ \\
\hline $\begin{array}{l}\text { Intercept } \\
\text { Race }\end{array}$ & $154.03 * * *$ & 2.32 & $149.26 * * *$ & 4.22 & $169.44 * * *$ & 4.57 & $150.79 * * *$ & 3.30 \\
\hline White & Reference & & Reference & & Reference & & Reference & \\
\hline Black & $-2.16 * * *$ & .242 & $-2.06 * * *$ & .097 & $-2.07 * * *$ & .126 & $-2.21 * * *$ & .052 \\
\hline Mulatto & $-1.51 * * *$ & .065 & $-1.23 * * *$ & .140 & $-1.53 * *$ & .205 & $-1.56 * * *$ & .080 \\
\hline Ages & & & & & & & & \\
\hline 14 & $-11.95 * * *$ & .436 & $-10.01 * * *$ & 1.31 & $-9.03 * * *$ & 1.67 & $-12.34 * * *$ & 467 \\
\hline 15 & $-8.27 * * *$ & .253 & $-8.31 * * *$ & .744 & $-7.00 * * *$ & .819 & $-8.46 * * *$ & .284 \\
\hline 16 & $-5.05 * * *$ & .130 & $-4.43 * * *$ & .407 & $-4.35 * * *$ & .422 & $-5.34 * * *$ & .144 \\
\hline 17 & $-3.12 * * *$ & .093 & $-3.00 * * *$ & .215 & $-2.91 * * *$ & .254 & $-3.25 * * *$ & .113 \\
\hline 18 & $-2.10 * * *$ & .074 & $-2.00 * * *$ & .172 & $-1.96 * * *$ & .212 & $-2.22 * * *$ & .090 \\
\hline 19 & $-1.09 * * *$ & .070 & $-.989 * * *$ & .148 & $-.894 * * *$ & .199 & $-1.20 * * *$ & .086 \\
\hline 20 & $-.458 * * *$ & .070 & $-.621 * * *$ & .145 & -.146 & .198 & $-.532 * * *$ & .088 \\
\hline 21 & $-.123 *$ & .067 & $-.314 * *$ & .131 & -.145 & .185 & -.116 & .085 \\
\hline 22 & .012 & .064 & -.113 & .123 & $-.511 * * *$ & .184 & .107 & .082 \\
\hline $20 s$ & Reference & & Reference & & Reference & & Reference & \\
\hline $30 \mathrm{~s}$ & .058 & .043 & $.117 *$ & .071 & -.197 & .126 & .015 & .060 \\
\hline $40 \mathrm{~s}$ & $-.306 * * *$ & .061 & .080 & .098 & $-.758 * * *$ & .161 & $-.451 * * *$ & .090 \\
\hline $50 \mathrm{~s}$ & $-.780 * * *$ & .093 & $-.420 * * *$ & .147 & $-1.50 * * *$ & .230 & $-.850 * * *$ & .142 \\
\hline $60 \mathrm{~s}$ & $-1.40 * * *$ & .162 & $-1.12 * * *$ & .272 & $-2.01 * * *$ & .329 & $-1.49 * * *$ & .255 \\
\hline $70 \mathrm{~s}$ & $-2.13 * * *$ & .351 & $-1.38 * * *$ & .578 & $-2.75 * * *$ & .714 & $-2.57 * * *$ & .552 \\
\hline Birth Decade & & & & & & & & \\
\hline $1800 \mathrm{~s}$ & $1.44 * * *$ & .198 & $1.06 * * *$ & .312 & $1.88 * * *$ & .427 & $1.20 * * *$ & .316 \\
\hline $1810 \mathrm{~s}$ & $1.38 * * *$ & .125 & $1.06 * * *$ & .207 & $1.93 * * *$ & .323 & $1.26 * * *$ & .177 \\
\hline $1820 \mathrm{~s}$ & $.992 * * *$ & .103 & $.789 * * *$ & .173 & $1.44 * * *$ & .267 & $.789 * * *$ & .146 \\
\hline $1830 \mathrm{~s}$ & $.267 * * *$ & .078 & .171 & .125 & .346 & .212 & .152 & .113 \\
\hline $1840 \mathrm{~s}$ & $-.140 * *$ & .057 & .008 & .097 & -.073 & .162 & $-.379 * * *$ & .079 \\
\hline $1850 \mathrm{~s}$ & $-.223 * * *$ & .049 & $-.338 * * *$ & .088 & -.237 & .146 & $-.211 * * *$ & .064 \\
\hline $1860 \mathrm{~s}$ & Reference & & Reference & & Reference & & Reference & \\
\hline $1870 \mathrm{~s}$ & $-.239 * * *$ & .049 & $-.270 * * *$ & .088 & $-.422 * * *$ & .142 & $-.147 * *$ & .064 \\
\hline $1880 \mathrm{~s}$ & $-.539 * * *$ & .056 & $-.243 * *$ & .106 & $-.707 * * *$ & .164 & $-.558 * * *$ & .073 \\
\hline $1890 \mathrm{~s}$ & $-.317 * * *$ & .072 & .218 & .140 & -.249 & .191 & $-.490 * * *$ & .094 \\
\hline $1900 \mathrm{~s}$ & .271 & .238 & -.541 & .459 & 1.01 & .559 & .277 & .311 \\
\hline Nativity & & & & & & & & \\
\hline Northeast & $-1.37 * * *$ & .131 & $-.753 * * *$ & .208 & $-1.39 * * *$ & .433 & $-1.44 * * *$ & .191 \\
\hline Middle Atlantic & $-1.73 * * *$ & .093 & $-1.28 * * *$ & .162 & $-1.99 * * *$ & .241 & $-1.58 * * *$ & .131 \\
\hline Great Lakes & $.149 * *$ & .070 & $.369 * * *$ & .124 & -.200 & .172 & .138 & .098 \\
\hline Plains & Reference & & Reference & & Reference & & Reference & \\
\hline Southeast & $.895 * * *$ & .058 & $.876 * * *$ & .116 & $.755 * * *$ & .160 & $.979 * * *$ & .075 \\
\hline Southwest & $2.80 * * *$ & .110 & $2.78 * * *$ & .225 & $1.87 * * *$ & .304 & $2.77 * * *$ & .141 \\
\hline Far West & $-.441 * * *$ & .135 & $.638 * * *$ & .264 & -.436 & .369 & $-.827 * * *$ & .174 \\
\hline
\end{tabular}




\begin{tabular}{|c|c|c|c|c|c|c|c|c|}
\hline $\begin{array}{l}\text { Migration } \\
\text { Migrant }\end{array}$ & $.497 * * *$ & .042 & $.508 * * *$ & .074 & -.124 & .119 & $.603 * * *$ & .058 \\
\hline $\begin{array}{l}\text { Non-Migrant } \\
\text { Migration }\end{array}$ & Reference & & Reference & & Reference & & Reference & \\
\hline $\begin{array}{l}\text { Direction } \\
\text { North-Short }\end{array}$ & $-.901 * * *$ & .060 & $-.673 * * *$ & .107 & -.599 & .174 & $-1.02 * * *$ & .079 \\
\hline North-Long & $-.596 * * *$ & .126 & $-.891 * * *$ & .243 & .372 & .248 & $-1.02 * * *$ & .183 \\
\hline South-Short & $.359 * * *$ & .054 & $.334 * * *$ & .086 & .188 & .169 & $.469 * * *$ & .077 \\
\hline $\begin{array}{l}\text { South-Long } \\
\text { Insolation }\end{array}$ & $1.13 * * *$ & .133 & $1.07 * * *$ & .196 & $1.87 * *$ & .744 & $1.20 * * *$ & .187 \\
\hline Insolation & $8.61 * * *$ & 1.10 & $10.97 * * *$ & 2.02 & $2.65 * * *$ & 2.25 & $9.79 * * *$ & 1.55 \\
\hline Insolation $^{2}$ & $-1.02 * * *$ & .132 & $-1.35 * * *$ & .242 & $-.382 * * *$ & .279 & $-1.12 * * *$ & .184 \\
\hline $\mathrm{N}$ & 183,378 & & 54,508 & & 22,494 & & 106,376 & \\
\hline $\mathrm{R}^{2}$ & .0689 & & .0421 & & .0441 & & .0842 & \\
\hline
\end{tabular}

Source: See Table 1.

Notes: Because US historical insolation is unavailable, a modern insolation index (19932003 ) is constructed, and monthly insolation values are measured from January thru June. The insolation index measures the hours of direct sunlight per day at county centroids in each state and is weighted by a county's square miles relative to square miles in the state. ${ }^{13}$ While this index is a rough approximation for historical insolation, it provides sufficient detail to capture state latitudinal insolation variation and consequently, vitamin D production. The US geographic classification scheme is consistent with Carlino and Sill (2000): New England= CT, ME, MA, NH, RI and VT; Middle Atlantic= DE, DC, MD, NJ, NY, and PA; Great Lakes= IL, IN, MI, OH, and WI; Plains=IA, KS, MN, MO, NE, ND, and SD; South East= AL, AR, FL, GA, KY, LA, MS, NC, SC, TN, VA, and WV; South West= AZ, NM, OK, and TX; Far West=CA, CO, ID, MT, NV, OR, UT, WA, and WA. *** Significant at .01; **Significant at .05; *Significant at .10.

\footnotetext{
${ }^{13}$ Insolation is not the insolation in the county that surround's the state's centroid, but insolation in each county's geographic center. The range of state insolation values extends from Maine's minimum of 3.43 hours of direct sunlight to Arizona's maximum of 5.22 hours of direct sunlight per day.
} 
Two general patterns emerge when comparing black and white stature variation by occupations. First, consistent with the stature-insolation hypothesis, individuals were taller in states that received - or moved to states that received - more insolation. For insolation levels equal to the average US insolation, an additional hour of insolation was associated with approximately one centimeter taller statures (Table 3, Model 1). Closely related with insolation are workers' occupations, which are also approximations for the number of hours exposed to solar radiation. Farmers, who spent more time outdoors, were taller than non-farmers, and farmers benefited from their close proximity to nutritious diets and mild disease environments. Workers in occupations with greater exposure to direct sunlight may have also been taller because they were exposed to more insolation as children and produced more vitamin D. Islam et al (2007, p. 383-388) demonstrate that children exposed to more direct sunlight produce more vitamin $\mathrm{D}$, and if there was little movement away from parental occupations, $19^{\text {th }}$ century occupations may be a good indicator for the occupational environment in which individuals came to maturity (Costa, 1993, p. 367; Margo and Steckel, 1992, p. 520). 
Figure 1, Nineteenth Century Stature Variation by Occupations

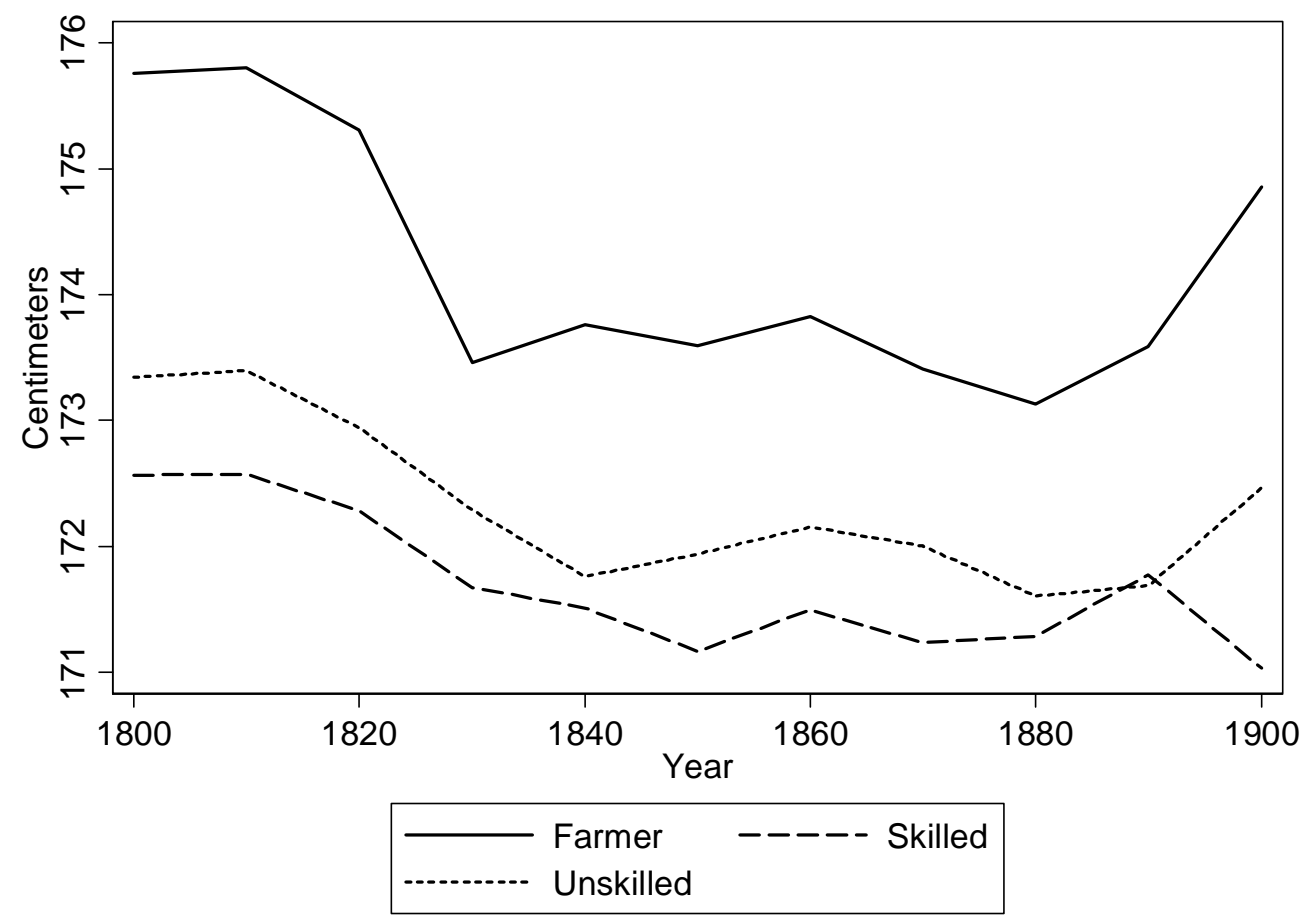

Source: See Table 2.

Notes: To simplify graphs, insolation was not included in these models.

Overtime farmer statures decreased by more than the statures of workers in other occupations (Figure 1). Nineteenth century US agricultural commercialization separated producers from consumers, and while farmers worked in rural agricultural environments, the rise of Northeastern urban centers, such as New York City, Boston, and Philadelphia, placed disproportionate stress on rural farmers, who lived near urban centers (Carson, 2008b, pp. 367-368). Urbanization created other pathways by which the costs of agricultural commercialization accrued to farmers. The proliferation of industrialization, urbanization, and agricultural commercialization compromised the quality of dairy and meat production, and in this pre-refrigeration period, food spoilage increased as the 
distance between rural farms and urban centers increased (Craig, et al, 2004). For example, although Southeastern Pennsylvanians were in close physical proximity to leading dairy producing Bucks, Chester, and Lancaster counties, they were also closer to urbanized Philadelphia, and individuals from Southeast Pennsylvania reached shorter terminal statures than individuals from rural Pennsylvania environments (Carson, 2008b, pp. 363-368).

Second, it is striking the degree to which average white statures exceeded black statures, and whites were between two and three centimeters taller than blacks. This is even more significant since modern black and white statures are comparable when brought to maturity under similar biological conditions (Eveleth and Tanner, 1976; Tanner, 1977; Steckel, 1995, p. 1910; Barondess, Nelson and Schlaen, 1997, p. 968; Komlos and Baur, 2004, pp. 64, 69; Nelson et al., 1993, pp. 18-20; Godoy et al, 2005, pp. 472-473). Moreover, compositional effects can-not explain the white-black stature differential, which was due, in part, to whites' access to meat and better nutrition (Margo and Steckel, 1982, pp. 514-515, 517, and 519). Mulatto statures also support the statureinsolation hypothesis because mulattos, who have less melanin in their stratum corneum, were taller than darker complected blacks but shorter than lighter complected whites.

Third, statures also varied by nativity, and after controlling for insolation, Southerners reached the tallest statures (Carson, 2008a, pp. 822-823; Carson, 2008b, 2008b, pp. 364-365). Moreover, immigrants who located to the South were taller than those who immigrated to the North, and part of the Southern migration advantage was related to Southern agriculture. The $19^{\text {th }}$ century opening of the New South to agriculture increased Southwestern agricultural productivity, which was higher than elsewhere in the 
US (Higgs, 1977, p. 24; Margo and Steckel, 1982, p. 519; Komlos and Coclanis, 1997, p. 443). Before the Civil War, the South was self-sufficient in food production, and relatively high white wages may have been associated with taller Southern white statures (Fogel, 1994, pp. 89, 132-133). After the Civil war, Southern wages in the West South Central were in general lower than Midwest wages and were comparable to those in the Middle Atlantic region. Blacks from the Great Lakes were taller than blacks from the Northeast and Plains. The relative price of dairy and calcium were lowest in dairy producing regions, such as Great Lake states, but $19^{\text {th }}$ century blacks were overwhelmingly native to the South. ${ }^{14}$ Northeasterners, especially blacks, encountered adverse biological environments, and contemporary reports of rickets - a result of vitamin D deficiency - may have contributed to shorter Northeastern statures (Kiple and Kiple, 1977, p. 293-294; Tortolani et al, 2002, p. 62). ${ }^{15}$ Therefore, as suggested by Holick (1981, p. 590), results presented here illustrate the primary sources of greater vitamin D production and statures were the number of hours exposed to sunlight, skin pigmentation, and nativity.

5. Explaining the Stature Advantage by Socioeconomic Status

\footnotetext{
${ }^{14}$ Southern observers at the time reported that milk was fairly abundant in border states but in short supply in the Deep South (Kiple and King, 1981, p. 83).

15 Stature is also related to air pollution, which interfered with the amount of insolation received (Holick, 1995; Tiwari and Puliyell, 2004, Agarwal et al, 2002), and Northerners near polluted industrial centers were shorter than rural Southerners who lived in less polluted in environments.
} 
To more fully account for the source of stature differentials by socioeconomic status, a Blinder-Oaxaca decomposition is imposed on the occupation stature differential (Oaxaca, 1973). Farmers are first compared to skilled workers; farmers are then compared to unskilled workers; lastly, skilled workers are compared to unskilled workers. Let $\mathrm{S}_{\mathrm{t}}$ and $\mathrm{S}_{\mathrm{s}}$ represent worker statures in the tallest and shortest occupations, respectively; $\alpha_{t}$ and $\alpha_{s}$ are the autonomous stature components that accrue to workers in taller and shorter occupations; $\beta_{\mathrm{t}}$ and $\beta_{\mathrm{s}}$ are the returns associated with specific stature enhancing characteristics, such as age and nativity. $X_{t}$ and $X_{s}$ are the characteristic matrices for individuals in taller and shorter occupations, and taller statures are assumed to be the base structure.

$$
\Delta S=S_{t}-S_{s}=\left(\alpha_{t}-\alpha_{s}\right)+\left(\beta_{t}-\beta_{s}\right) X_{s}+\beta_{t}\left(X_{t}-X_{s}\right)
$$

The second right hand-side element is that component of the stature differential due to differences in stature returns, and since occupations are ordered according to stature rank, was likely positive for most characteristics. The third right-hand side element is the stature differential component due to characteristic differences and is also likely positive because farmers probably had characteristics associated with taller statures. Hence, if the biological advantage to workers in occupations with taller statures were due to superior biological conditions, the stature returns, $\beta_{t}$, will be larger than stature returns to short stature occupations, $\beta_{\mathrm{s}}$. 
Table 4, Nineteenth Century National Prison Stature Oaxaca Decomposition by Socioeconomic Status

\begin{tabular}{|c|c|c|c|c|}
\hline & Oaxaca I & & Oaxaca II & \\
\hline $\begin{array}{l}\text { Farmers- } \\
\text { Skilled }\end{array}$ & $\left(\beta_{f}-\beta_{s}\right) \bar{X}$ & $\left.\bar{X}_{f}-\bar{X}_{s}\right) \beta$ & $\left(\beta_{f}-\beta_{s}\right) \bar{X}$ & $\left.{ }_{f}-\bar{X}_{s}\right) \beta_{s}$ \\
\hline Levels & & & & \\
\hline Sum & -74.19 & -.172 & -41.65 & -.020 \\
\hline Total & & -74.36 & & -41.67 \\
\hline Proportions & & & & \\
\hline Intercept & -.158 & & -.282 & \\
\hline Race & .017 & .010 & .053 & .010 \\
\hline Ages & .574 & .002 & .846 & .005 \\
\hline Birth & -.020 & $9.56^{-5}$ & -.096 & $-1.5^{-4}$ \\
\hline Nativity & -.032 & -.011 & -.129 & -.019 \\
\hline Migration & .021 & -.001 & -.073 & .003 \\
\hline Insolation & .596 & .002 & .680 & .002 \\
\hline Sum & .998 & .002 & .999 & .001 \\
\hline Total & & 1 & & 1 \\
\hline $\begin{array}{l}\text { Farmers- } \\
\text { Unskilled }\end{array}$ & & & & \\
\hline Levels & & & & \\
\hline Total & -120.82 & .176 & -63.97 & .279 \\
\hline Sum & & -120.65 & & -63.69 \\
\hline Proportions & & & & \\
\hline Intercept & -.129 & & -.243 & \\
\hline Race & -.010 & $-6.1^{-4}$ & -.020 & -.001 \\
\hline Ages & .505 & $-2.4^{-4}$ & .707 & .001 \\
\hline Birth & -.021 & $-6.4^{-4}$ & -.080 & $-4.9^{-4}$ \\
\hline Nativity & .019 & -.002 & .018 & -.004 \\
\hline Migration & .009 & $-2.7^{-4}$ & -.056 & $9.2^{-5}$ \\
\hline Insolation & .628 & .002 & .678 & .003 \\
\hline Sum & 1.00 & 0 & 1.00 & 0 \\
\hline Total & & 1.00 & & 1.00 \\
\hline Skilled- & & & & \\
\hline Levels & & & & \\
\hline Total & -72.99 & .459 & -53.65 & .235 \\
\hline Sum & & -72.53 & & -53.42 \\
\hline Proportions & & & & \\
\hline Intercept & -.052 & & -.071 & \\
\hline Race & .088 & -.007 & .072 & -.015 \\
\hline Ages & .628 & -.004 & .663 & -.006 \\
\hline Birth & .021 & $5.7^{-4}$ & -.001 & $-8.4^{-4}$ \\
\hline Nativity & .033 & .008 & .006 & .012 \\
\hline
\end{tabular}




\begin{tabular}{l|cccc}
\hline Migration & -.004 & -.001 & -.011 & -.001 \\
Insolation & .293 & $-7.1^{4}$ & .346 & .006 \\
Sum & 1.01 & -.01 & 1.00 & 0 \\
\cline { 1 - 1 } Total & & 1 & & 1 \\
\hline
\end{tabular}

Source: See Tables 1 and 3.

For each comparison, the majority of the occupational stature gap is associated with returns to age and insolation (Table 4); characteristics associated with stature remained noticeably insignificant. Stature by occupation illustrates farmers were, on average, taller and had greater stature returns with insolation than workers in other occupations; farmers also had larger stature returns associated with age. Race (skin pigmentation) explained a small share of the stature gap, and stature differentials due to nativity were smaller than exposure to insolation. Therefore, stature differentials by socioeconomic status support that a population's greatest source of $19^{\text {th }}$ century stature gains through vitamin D were hours spent outdoors, skin pigmentation, and nativity (Holick, 1981, p. 590).

\section{Conclusion}

This study considers the three most important sources of a population's stature variation by vitamin $\mathrm{D}$ production, and illustrates that in each case, hours of direct sunlight was the primary source of $19^{\text {th }}$ century stature variation. Farmers, who traditionally worked outdoors and were exposed to more direct sunlight, were taller than workers in other occupations. At North American latitudes, more melanin in their epidermises also prevented African-Americans from reaching taller statures. Nativity influenced stature, and workers native to the South were taller than workers located 
further north from the equator and the beneficial effects of direct solar radiation.

Therefore, rather than only sociological processes and access to nutrition explaining a population's stature variation, part of $19^{\text {th }}$ century stature variation was biologically based. 
References

Agarwal, KS, MZ Mughal, P Upadhyay, JL Berry, EB Mawer, JM Puliyel (2002) “The Impact of Atmospheric Pollution on Vitamin D Status on Infants and Toddlers in New Delhi," Archives of Disease in Children, 87: 111-113.

Atack J, Bateman F (1987) To Their Own Soil: Agriculture in the Antebellum North. Iowa State University Press Ames, Iowa

Barondess DA, Nelson DA, Schlaen S (1997) Whole Body Bone, Fat and Lean Mass in Black and White Men. Journal of Bone and Mineral Research $12: 967-971$

Bleakley H (2003) Disease and Development: Evidence from the American South. Journal of the European Economic Association 1(2):376-386

Bodenhorn H (1999) A Troublesome Caste: Height and Nutrition of Antebellum Virginia’s Rural Free Blacks. Journal of Economic History 59(4):972-996 Bodenhorn H (2002) Mulatto Advantage: The Biological Consequences of Complexion in Rural Antebellum Virginia. Journal of Interdisciplinary History $33(1): 21-46$

Bogin B (1988) Patterns of Human Growth. Cambridge University Press, Cambridge, UK

Bogin B (1991) Measurement of Growth Variability and Environmental Quality in Guatemalan Children. Annals of Human Biology 18(4):285-294.

Breeden J (1988) Disease and Southern Distinctiveness. In: Savitt TL, Young JA (eds) Disease and Distinctiveness in the American South. University of Tennessee Press, Knoxville, TN 
Brinkley GL (1997) The Decline in Southern Agricultural Output, 1860-1880. Journal of Economic History 57(1):116-138

Carson SA (2005) The Biological Standard of Living in $19^{\text {th }}$ Century Mexico and the American West. Economics and Human Biology 3(3):405-419

Carson, Scott Alan. (2008a) "The Effect of Geography and Vitamin D on AfricanAmerican Stature in the Nineteenth Century: Evidence from Prison Records," Journal of Economic History. 68(3), pp. 812-831.

Carson, SA (2008b) "Health During Industrialization: Evidence from the NineteenthCentury Pennsylvania State Prison System,” Social Science History 32(3), pp. 347-372.

Carson, Scott Alan (forthcoming). "Geography, Insolation, and Vitamin D in $19^{\text {th }}$ Century US African-American and White Statures," Explorations in Economic History.

Coclanis PA, Komlos J (1995) Nutrition and Economic Development in Post Reconstruction South Carolina. Social Science History 19(1):91-115

Coelho P, McGuire R (2000) Diets versus Disease: the Anthropometrics of Slave Children. Journal of Economic History 60(1):232-46

Craig, Lee A., Barry Goodwin, and Thomas Grennes. 2004. “The Effect of Mechanical Refrigeration on Nutrition in the U. S." Social Science History. 28(2): 325-336. Crouch BA (1984) Sprit of Lawlessness: White Violence; Texas Blacks, 1865-1868. Journal of Social History 18(2):217-232 Cuff T (1992) A Weighty Issue Revisited: New Evidence on Commercial Swine 
Weights and Pork Production in Mid-Nineteenth Century America. Agricultural History 66(4): 55-74

Cuff T (2004) Historical Anthropometrics. EH.Net Encyclopedia, edited by Robert Whaples. URL http://eh.net/encyclopedia/article/cuff.anthropometric David P, Temin P (1976) Capitalist Masters and Bourgeois Slaves. In: David P, Gutman H, Sutch R, Wright, G (eds) Reckoning With Slavery. Oxford University Press, New York, NY

Easterlin R (1971) Regional Income Trends, 1840-1950. In: Fogel RF, Engerman, SL (eds) The Reinterpretation of American Economic History. Harper \& Row, New York, NY:38-53

Eveleth PB, Tanner JM (1976) Worldwide Variation in Human Growth $2^{\text {nd }}$ edn. Cambridge University Press, Cambridge, UK

Ferrie JP (1997) The Entry into the U.S. Labor Market or Antebellum European Immigrants, 1840-1860. Explorations in Economic History 34(3):295-33

Ferrie JP (1999) Yankees Now: Immigrants in the Antebellum United States, 1840-1860.

Oxford University Press and the National Bureau of Economic Research, New York. NY

Fite G (1986) The Agricultural Trap in the South. Agricultural History 60(4):38-50 Fogel RW, Engerman SL (1974) Time on the Cross: The Economics of American Negro Slavery. W. W. Norton, New York, NY

Fogel, Robert W. "Economic Growth, Population Theory and Physiology: The Bearing of Long-Term Processes on the Making of Economic Policy," American Economic Review 84(3), 1994, pp. 369-395. 
Fogel RW, Engerman SL, Trussell J, Floud R, Pope C, Wimmer L (1978) Economics of Mortality in North America, 1650-1910: A Description of a Research Project. Historical Methods 11(2):75-108

Fogel RW, Engerman SL, Floud R, Friedman F, Margo R, Sakoloff K, Steckel R, Trussell J, Villaflor G, Wachter K (1983) Secular Changes in American and British Stature and Nutrition. Journal of Interdisciplinary History 14(2):445-481 Friedman LM (1993) Crime and Punishment in American History. Basic Books, New York, NY

Garland, Cedric F, Frank Garland, Edward Gorhom, Margin Lipkin, Harold Newmark, Sharif Mohr, and Michael Holick. (2006) "The Role of Vitamin D in Cancer Prevention.” American Journal of Public Health. 96(2). pp. 252-261.

Ginsburg, E, G. Livshits, K. Yakovenko and E. Kobyliansky, "Major Gene Control of Human Body Height, Weight and BMI in Five Ethnically Different Populations," Annals of Human Genetics, 62, 1998, pp. 307-322.

Godoy RE, Goodman R, Levins R, Leonard WR (2005) Anthropometric Variability in the USA. Annals of Human Biology 32(4):469-485

Goodman AH, Martin DL (2002) Reconstructing Health Profiles from Skeletal Remains. In: Steckel R, Rose JC (eds) The Backbone of History. Cambridge University Press, Cambridge, UK:11-60.

Grant, William (2003) "Ecological Studies of Solar UV-B Radiation and Cancer Mortality Rates," Resent Results in Cancer Research. 164, pp. 371-377.

Haines M, Craig L, Weiss T (2003) The Short and the Dead: Nutrition, Mortality and the "Antebellum Puzzle" in the United States. Journal of Economic 
History 63(2):382-413

Haines M (2004) Growing Incomes, Shrinking People_Can Economic Development be Hazardous to Your Health? Social Science History 28(4):249-270

Harris JW (2006) The Making of the American South: a Short History, 1500-1877.

Blackwell Publishing, Oxford, England

Higgs R (1977) Competition and Coercion. University of Chicago Press, Chicago, IL Hilliard SB (1972) Hog, Meat and Hoecake: Food Supply in the Old South, 1840-

1860. Southern Illinois University Press, Carbondale, IL.

Holick, Michael F., A. MacLaughlin, and S. H. Doppelt (1981) "Regulation of Cutaneous

Previtamin $\mathrm{D}_{3}$ Photosynthesis in Men: Skin Pigment is not an Essential

1861. Regulator.” Science, 211(6), pp. 590-593.

Holick, Michael (1995) "Environmental Factors that Influence the Cutaneous Production of Vitamin D,” American Journal of Clinical Nutrition, 61 (suppl): 638S-645S.

Holick, Michael F, "Vitamin D: Importance in the Prevention of Cancers, Type 1

Diabetes, Heart Disease and Osteroporosis." American Journal of Clinical Nutrition 79. 2004a. pp. 362-371.

Holick, Michael, 2004b, "Sunlight and Vitamin D for Bone Health and Prevention of Autoimmune Diseases, Cancers, and Cardiovascular Diseases," American Journal of Clinical Nutrition, supplement, pp. 1678S-1688S.

Holick, Michael F, 2007 “Vitamin D Deficiency.” New England Journal of Medicine 357(3). pp. 266-281.

Islam, Talat, W. James Gauderman, Wendy Cozen, Thomas Mack, 2007, “Childhood Sun Exposure Influences Rick of Multiple Sclerosis in Monozygotic Twins,” 
Neurology 69, pp. 381-388.

Jablonski, Nina (2006) Skin: A Natural History. Berkeley: University of California Press. Johnston FE, Zimmer LO (1989) Assessment and Growth in the Immature Skeleton.

In: Iscan M.Y, Kennedy KA (eds) Reconstruction of Life from the Skeleton.:

Alan R. Liss, New York, NY: 11-22

Kaidbey, Kays, Patricia Poh Agin, Robert Sayre, and Albert Cligman (1979)

"Photoprotection of Melanin: a Comparison of Black and Caucasian Skin." Journal of the American Academy of Dermatology 1(3). pp. 249-260.

Kiple, Kenneth and Virginia Kiple, 1977, "Slave Child Mortality: Some Nutritional Answers to a Perennial Puzzle,” Journal of Social History 10, pp. 284-309.

Komlos J (1985) Stature and Nutrition in the Habsburg Monarchy: The Standard of Living and Economic Development in the Eighteenth Century. American Historical Review 90(5):1149-61

Komlos J (1987) The Height and Weight of West Point Cadets: Dietary Change in Antebellum America. Journal of Economic History 47(4):897-927

Komlos J (1992) Toward an Anthropometric History of African-Americans: The Case of the Free Blacks in Antebellum Maryland. In: Goldin C, Rockoff H (eds) Strategic Factors in Nineteenth Century American Economic History: A Volume to Honor Robert W. Fogel, University of Chicago Press, Chicago, IL:297-329

Komlos J (1996) Anomalies in Economic History: Toward a Resolution on the Antebellum Puzzle. Journal of Economic History 56(1):202-214

Komlos J (1998) Shrinking in a Growing Economy? The Mystery of Physical Stature during the Industrial Revolution. Journal of Economic History 58(3):779-802 
Komlos J, Alecke B (Winter, 1996) The Economics of Antebellum Slave Heights Reconsidered. Journal of Interdisciplinary History 26(3):437-457

Komlos J, Coclanis P (1997) On the Puzzling Cycle in the Biological Standard of Living: The Case of Antebellum Georgia. Explorations in Economic History $34(4): 433-59$

Komlos J, Baur M (2004) From Tallest to (one of) the Fattest: the Enigmatic Fate of American Population in the $20^{\text {th }}$ Century. Economics and Human Biology 2(1):57-74

Komlos, John and Jörg Baten (2004) “Anthropometric Research and the Development of Social Science History. Social Science History. 28: 191-210.

Ladurie LE (1979) The Conscripts of 1968: A Study of the Correlation between Geographical Mobility, Delinquency and Physical Stature and Other Aspects of the Situation of the Young Frenchman Called to Do Military Service that Year. In: Reynolds B, Reynolds S (eds) The Territory of the Historian, University of Chicago Press, Chicago, IL:33-60.

Loomis, W. Farnsworth, 1967, "Skin-Pigment Regulation of Vitamin-D Biosynthesis in Man: Variation in Solar Ultraviolet at Different Latitudes may have Caused Racial Differentiation in May," Science, pp. 501-506.

Lynch J, Kaplan G (1997) Understanding How Inequality in the Distribution of Income Affects Human Health. Journal of Health Psychology 2(3): 297-314 Maloney TN (1992) Degrees of Inequality: the Advance of Black Workers in Northern Meatpacking and Steel Industries, 1910-1940. Social Science History 19(1):3162 
Marable M (1979) The Politics of Black Land Tenure, 1877-1915. Agricultural History 53: 142-152

Margo R, Steckel R (1982) Heights of American Slaves: New Evidence on Nutrition and Health. Social Science History 6(4):516-538

Margo R, Steckel R (1983) Heights of Native Born Northern Whites during the Antebellum Era. Journal of Economic History 43(1):167-174

Margo R, Steckel R (1992) The Nutrition and Health of Slaves and antebellum Southern whites. In: Fogel RW, Engerman SL (eds) Without Consent or Contract: Conditions of Slave Life and the Transition to Freedom. W. W. Norton New York, NY:508-521

Metzer JM (1975) Rational Management, Modern Business Practices and Economies of Scale in Antebellum Southern Plantations. Explorations in Economic History $12(2): 123-150$

Mokkonen E (2002) Crime, Justice, History. The Ohio State University Press, Columbus, $\mathrm{OH}$

Nelson, D., Kleerekoper, M., Peterson E. \& A. M. Parfitt, (1993) “Skin Color and Body Size as Risk Factors for Osteoporosis,” Osteoporosis International, 3, $18-23$.

Nesby-O’Dell, Shanna, Kelley Scanlon, Mary Cogswell, Cathleen Gillesie, Bruce Hollis Anne Looker, Chris Allen, Cindy Doughertly, Elaine Gunter, and Barbara Bowman. "Hypovitaminosis D Prevalence and Determinants among AfricanAmerican and White Woman of Reproductive Age: Third National Health and 
Nutrition Examination Survey, 1988-1994.” American Journal Clinical Nutrition 76. 2002. pp. 187-192.

Norman, Anthony, "Sunlight, Season, Skin Pigmentation, Vitamin D and 25hydroxyvatamin D: Integral Components of the Vitamin D Endocrine System," American Journal of Clinical Nutrition, 67. 1998, pp. 1108-1110.

Oaxaca RL (1973) Male Female Wage Differentials in Urban Labor Markets. International Economic Review 14(3):693-709

Pritchett JB, Freudenberger H (1992) A Peculiar Sample: the Selection of Slaves for the New Orleans Market. Journal of Economic History 52(1): 107-27 Ransom R, Sutch R (1977) One Kind of Freedom: the Economic Consequences of Emancipation. Cambridge University Press, Cambridge, UK

Rees R, Komlos J, Long N, Woitek U (2003) Optimal Food Allocation in a Slave Economy. Journal of Population Economics 16:21-36

Reid JD (1979) White Land, Black Labor and Agricultural Stagnation: The Causes and Effects of Sharecropping in the Postbellum South. Explorations in Economic History 16(1):31-55.

Rose J (1989) Biological Consequences of Segregation and Economic Depravity: A Post-Slavery Population from Southwest Arkansas. Journal of Economic History 49(2): $351-360$

Rosenbloom J (2002) Looking for Work, Searching for Workers: American Labor Markets during Industrialization. Cambridge University Press, Cambridge, UK Sokoloff KL, Villaflor GC (1982) The Early Achievement of Modern Stature in America. Social Science History 6(4):453-481 
Soltow L (1975) Men and Wealth in the United States, 1850-1870. Yale University Press, New Haven, CT

Steckel R (1979) Slave Height Profiles from Coastwise Manifests. Explorations in Economic History 16:363-380

Steckel R (1992) Work, Disease and Diet in the Health and Mortality of American Slaves. In: Fogel RF, Engerman SL (eds) Without Consent or Contract: Conditions of Slave Life and the Transition to Freedom, Technical Papers, v. 2. W.W. Norton: New York, NY

Steckel R (1983) The Economic Foundations of East-West Migration during the $19^{\text {th }}$ Century. Explorations in Economic History 20(1):14-36

Steckel R (1986) A Peculiar Population: The Nutrition, Health, and Mortality of American Slaves from Childhood to Mortality. Journal of Economic History 46(3):721-41

Steckel R (1989) Household Migration and Settlement in the United States, 1850-1860. Explorations in Economic History 26(2):190-218 Steckel R (1992) Work, Disease and Diet in the Health and Mortality of American Slaves. In: Fogel RW, Engerman SL (eds) Without Consent or Contract: The Rise and Fall of American Slavery, Conditions of Slave Life and the Transition to Freedom: Technical Papers. W. W. Norton, New York, NY:489-507

Steckel R (1994) Heights and Health in the United States. In: Komlos, J (ed) Stature, Living Standards and Economic Development. University of Chicago Press, Chicago, IL: 153-170

Steckel, R (1995) Stature and the Standard of Living. Journal of Economic 
Literature 33(4):1903-40

Steckel, R (2000) Diets versus Disease in the Anthropometrics of Slave Children: A Reply. Journal of Economic History, 60(1):247-259.

Steckel R, Haurin D (1994) Health and Nutrition in the American Midwest:

Evidence from the Height of Ohio National Guardsman. 1850-1910. In: Komlos J (ed) Stature, Living Standards and Economic Development. Chicago University Press, Chicago, IL:117-128

Sunder, Marco (2004) "The Height of Tennessee Convicts: Another Pieces of the “Antebellum Puzzle”. Economics and Human Biology. pp. 75-86.

Sutch R (1975) The Treatment Received by American Slaves: A Critical Review of the Evidence Presented in Time on the Cross. Explorations in Economic History $12(4): 335-438$

Tanner JM (1962) Growth at Adolescence. Charles C. Thomas, Springfield, IL Tanner JM (1977) Hormonal, Genetic and Environmental Factors Controlling Growth. In: Harrison GA, Weiner JS, Tanner JM, Barnicot NA (eds) Human Biology: an Introduction to Human Evolution, Variation, Growth and Ecology, $2^{\text {nd }}$ Ed. Oxford University Press, Oxford, England:335-351

TEXAS STATE PENITENTIARY AT HUNTSVILLE. The Handbook of Texas Online. http://www.tsha.utexas.edu/handbook/online/articles/view/TT/jjt1.html Tiwari, Lokesh and Jacob Puliyel (2004) "Vitamin D Levels in Slum Children of Delhi," Indian Pediatrician, 41(10), pp. 1076-1077.

Tortolani, Justin, Edward McCarthy, Paul Sponseller, 2002, “Bone Mineral Density Deficiency in Children," Journal of the American Academy of Orthopedic 
Surgeons, 10(1) pp. 57-66.

Troesken W (2004) Water, Race and Disease. MIT Press, Cambridge, UK

Utterlinden, André, Yue Fang, Joyce B.J. van Meurs, Huibert A. P. Pols, Johannes P.T.M van Leeuwen, "Genetic and Biology of Vitamin D Receptor Polymorphisms," Gene, 338, 2004, pp. 143-156.

Wahl JB (1996) The Jurisprudence of American Slave Sales. Journal of Economic History 56(1):143-69

Wahl JB (1997) Legal Constraints on Slave Masters: The Problem of Social Cost. The American Journal of Legal History 41(1):1-24

Walker DR (1988) Penology for Profit: a History of the Texas Prison System, 1867-

1912. Texas A \& M University Press, College Station

Wardlaw, G.M., J.S. Hampl, and R.A. Disilestro, 2004, Perspectives in Nutrition, $6^{\text {th }}$ ed., New York: McGraw-Hill, pp. 394-397.

Weisberg, Pamela, Kelley Scanlon, Ruowei Li, and Mary E. Cogswell. "Nutritional Rickets Among Children in the United States: Review of Cases Reported between 1986 and 2003." American Journal of Nutrition 80 (suppl), 2004, pp.1697S1705 S.

Woodward VC (1951) Origins of the new South, 1877-1913. Louisiana State University Press, Baton Rouge, LA

Wright G (1978) The Political Economy of the Cotton South: Households, Markets, and Wealth in the Nineteenth Century. W. W. Norton, New York, NY. 
Xiong, E-H, F-H Xu, P-Y Liu, H Shen, J-R Long, L Elze, R R Recker and H-W Deng, "Vitamin D Receptor Gene Polymorphisms are Linked to and Associated with Adult Height,” Journal of Medical Genetics, 42, 2004, pp. 228-234.

Y-Z Liu, F-H Shen, H Deng, Y-J Liu, L-J Zhao, V Dvornyk, T Conway, J-L Li, Q-Y Huang, K M Davies, R R Recker, and H-W Deng, “Confirmation Linkage Study in Support of the X Chromosome Harbouring a ATL Underlying Human Height Variation," Journal of Medical Genetics, 40, pp. 825-831. 


\section{CESifo Working Paper Series}

for full list see www.cesifo-group.org/wp

(address: Poschingerstr. 5, 81679 Munich, Germany, office@cesifo.de)

2433 Kurt R. Brekke and Odd Rune Straume, Pharmaceutical Patents: Incentives for R\&D or Marketing?, October 2008

2434 Scott Alan Carson, Geography, Insolation, and Institutional Change in $19^{\text {th }}$ Century African-American and White Stature in Southern States, October 2008

2435 Emilia Del Bono and Daniela Vuri, Job Mobility and the Gender Wage Gap in Italy, October 2008

2436 Marco Angrisani, Antonio Guarino, Steffen Huck and Nathan Larson, No-Trade in the Laboratory, October 2008

2437 Josse Delfgaauw and Robert Dur, Managerial Talent, Motivation, and Self-Selection into Public Management, October 2008

2438 Christian Bauer and Wolfgang Buchholz, How Changing Prudence and Risk Aversion Affect Optimal Saving, October 2008

2439 Erich Battistin, Clara Graziano and Bruno Parigi, Connections and Performance in Bankers' Turnover: Better Wed over the Mixen than over the Moor, October 2008

2440 Erkki Koskela and Panu Poutvaara, Flexible Outsourcing and the Impacts of Labour Taxation in European Welfare States, October 2008

2441 Marcelo Resende, Concentration and Market Size: Lower Bound Estimates for the Brazilian Industry, October 2008

2442 Giandomenico Piluso and Roberto Ricciuti, Fiscal Policy and the Banking System in Italy. Have Taxes, Public Spending and Banks been Procyclical in the Long-Run? October 2008

2443 Bruno S. Frey and Katja Rost, Do Rankings Reflect Research Quality?, October 2008

2444 Guglielmo Maria Caporale, Antoaneta Serguieva and Hao Wu, Financial Contagion: Evolutionary Optimisation of a Multinational Agent-Based Model, October 2008

2445 Valentina Bosetti, Carlo Carraro and Massimo Tavoni, Delayed Participation of Developing Countries to Climate Agreements: Should Action in the EU and US be Postponed?, October 2008

2446 Alexander Kovalenkov and Xavier Vives, Competitive Rational Expectations Equilibria without Apology, November 2008

2447 Thiess Buettner and Fédéric Holm-Hadulla, Cities in Fiscal Equalization, November 2008 
2448 Harry H. Kelejian and Ingmar R. Prucha, Specification and Estimation of Spatial Autoregressive Models with Autoregressive and Heteroskedastic Disturbances, November 2008

2449 Jan Bouckaert, Hans Degryse and Thomas Provoost, Enhancing Market Power by Reducing Switching Costs, November 2008

2450 Frank Heinemann, Escaping from a Combination of Liquidity Trap and Credit Crunch, November 2008

2451 Dan Anderberg, Optimal Policy and the Risk Properties of Human Capital Reconsidered, November 2008

2452 Christian Keuschnigg and Evelyn Ribi, Outsourcing, Unemployment and Welfare Policy, November 2008

2453 Bernd Theilen, Market Competition and Lower Tier Incentives, November 2008

2454 Ondřej Schneider, Voting in the European Union - Central Europe's Lost Voice, November 2008

2455 Oliver Lorz and Gerald Willmann, Enlargement versus Deepening: The Trade-off Facing Economic Unions, November 2008

2456 Alfons J. Weichenrieder and Helen Windischbauer, Thin-Capitalization Rules and Company Responses, Experience from German Legislation, November 2008

2457 Andreas Knabe and Steffen Rätzel, Scarring or Scaring? The Psychological Impact of Past Unemployment and Future Unemployment Risk, November 2008

2458 John Whalley and Sean Walsh, Bringing the Copenhagen Global Climate Change Negotiations to Conclusion, November 2008

2459 Daniel Mejía, The War on Illegal Drugs in Producer and Consumer Countries: A Simple Analytical Framework, November 2008

2460 Carola Frydman, Learning from the Past: Trends in Executive Compensation over the Twentieth Century, November 2008

2461 Wolfgang Ochel, The Political Economy of Two-tier Reforms of Employment Protection in Europe, November 2008

2462 Peter Egger and Doina Maria Radulescu, The Influence of Labor Taxes on the Migration of Skilled Workers, November 2008

2463 Oliver Falck, Stephan Heblich and Stefan Kipar, The Extension of Clusters: Differencein-Differences Evidence from the Bavarian State-Wide Cluster Policy, November 2008

2464 Lei Yang and Keith E. Maskus, Intellectual Property Rights, Technology Transfer and Exports in Developing Countries, November 2008 
2465 Claudia M. Buch, The Great Risk Shift? Income Volatility in an International Perspective, November 2008

2466 Walter H. Fisher and Ben J. Heijdra, Growth and the Ageing Joneses, November 2008

2467 Louis Eeckhoudt, Harris Schlesinger and Ilia Tsetlin, Apportioning of Risks via Stochastic Dominance, November 2008

2468 Elin Halvorsen and Thor O. Thoresen, Parents' Desire to Make Equal Inter Vivos Transfers, November 2008

2469 Anna Montén and Marcel Thum, Ageing Municipalities, Gerontocracy and Fiscal Competition, November 2008

2470 Volker Meier and Matthias Wrede, Reducing the Excess Burden of Subsidizing the Stork: Joint Taxation, Individual Taxation, and Family Splitting, November 2008

2471 Gunther Schnabl and Christina Ziegler, Exchange Rate Regime and Wage Determination in Central and Eastern Europe, November 2008

2472 Kjell Erik Lommerud and Odd Rune Straume, Employment Protection versus Flexicurity: On Technology Adoption in Unionised Firms, November 2008

2473 Lukas Menkhoff, High-Frequency Analysis of Foreign Exchange Interventions: What do we learn?, November 2008

2474 Steven Poelhekke and Frederick van der Ploeg, Growth, Foreign Direct Investment and Urban Concentrations: Unbundling Spatial Lags, November 2008

2475 Helge Berger and Volker Nitsch, Gotcha! A Profile of Smuggling in International Trade, November 2008

2476 Robert Dur and Joeri Sol, Social Interaction, Co-Worker Altruism, and Incentives, November 2008

2477 Gaëtan Nicodème, Corporate Income Tax and Economic Distortions, November 2008

2478 Martin Jacob, Rainer Niemann and Martin Weiss, The Rich Demystified - A Reply to Bach, Corneo, and Steiner (2008), November 2008

2479 Scott Alan Carson, Demographic, Residential, and Socioeconomic Effects on the Distribution of $19^{\text {th }}$ Century African-American Stature, November 2008

2480 Burkhard Heer and Andreas Irmen, Population, Pensions, and Endogenous Economic Growth, November 2008

2481 Thomas Aronsson and Erkki Koskela, Optimal Redistributive Taxation and Provision of Public Input Goods in an Economy with Outsourcing and Unemployment, December 2008 
2482 Stanley L. Winer, George Tridimas and Walter Hettich, Social Welfare and Coercion in Public Finance, December 2008

2483 Bruno S. Frey and Benno Torgler, Politicians: Be Killed or Survive, December 2008

2484 Thiess Buettner, Nadine Riedel and Marco Runkel, Strategic Consolidation under Formula Apportionment, December 2008

2485 Irani Arraiz, David M. Drukker, Harry H. Kelejian and Ingmar R. Prucha, A Spatial Cliff-Ord-type Model with Heteroskedastic Innovations: Small and Large Sample Results, December 2008

2486 Oliver Falck, Michael Fritsch and Stephan Heblich, The Apple doesn't Fall far from the Tree: Location of Start-Ups Relative to Incumbents, December 2008

2487 Cary Deck and Harris Schlesinger, Exploring Higher-Order Risk Effects, December 2008

2488 Michael Kaganovich and Volker Meier, Social Security Systems, Human Capital, and Growth in a Small Open Economy, December 2008

2489 Mikael Elinder, Henrik Jordahl and Panu Poutvaara, Selfish and Prospective: Theory and Evidence of Pocketbook Voting, December 2008

2490 Maarten Bosker and Harry Garretsen, Economic Geography and Economic Development in Sub-Saharan Africa, December 2008

2491 Urs Fischbacher and Simon Gächter, Social Preferences, Beliefs, and the Dynamics of Free Riding in Public Good Experiments, December 2008

2492 Michael Hoel, Bush Meets Hotelling: Effects of Improved Renewable Energy Technology on Greenhouse Gas Emissions, December 2008

2493 Christian Bruns and Oliver Himmler, It's the Media, Stupid - How Media Activity Shapes Public Spending, December 2008

2494 Andreas Knabe and Ronnie Schöb, Minimum Wages and their Alternatives: A Critical Assessment, December 2008

2495 Sascha O. Becker, Peter H. Egger, Maximilian von Ehrlich and Robert Fenge, Going NUTS: The Effect of EU Structural Funds on Regional Performance, December 2008

2496 Robert Dur, Gift Exchange in the Workplace: Money or Attention?, December 2008

2497 Scott Alan Carson, Nineteenth Century Black and White US Statures: The Primary Sources of Vitamin D and their Relationship with Height, December 2008 